\title{
Mechanically deboned turkey meat with improved digestibility and biological value
}

\author{
K. Takács* ㅌ, E. Szerdahelyi, A. Nagy and É. Gelencsér
}

Food Science Research Group, Institute of Food Science and Technology, Hungarian University of Agriculture and Life Sciences, Herman Ottó út 15., H-1022 Budapest, Hungary

\section{ORIGINAL RESEARCH PAPER}

Received: November 16, 2020 • Accepted: March 1, 2021

Published online: May 15, 2021

(C) 2021 The Author(s)

\begin{abstract}
Enzymatic hydrolysates of mechanically deboned meat (MDM) for a long time have been used as flavouring and functional food ingredients in the food industry and also as the bases of formula foods for special dietary uses.

The aim of the present study was to produce MDM hypo-antigenic products with improved digestibility and high biological value to be used as a milk protein alternative. turkey MDM was treated with digestive enzymes (trypsin and/or $\alpha$-chymotrypsin, or pancreatin), followed by freeze drying. The optimised reaction conditions of hydrolysis were at $6 \%(\mathrm{w} / \mathrm{v})$ of meat protein in $0.1 \% \mathrm{NaHCO}_{3}$ buffer, $\mathrm{pH} 7.5$; pancreatin enzyme with 50 TAME units/g meat protein substrate, $37{ }^{\circ} \mathrm{C}$ and $60 \mathrm{~min}$ ). Hydrolysates $(\mathrm{MDMH})$ were assessed for degree of hydrolyses $(\mathrm{DH}, \%)$ by using trinitrobenzenesulphonic acid method and MW distribution by SDS-PAGE. Modification of immune reactive binding sites in MDMHs was monitored by immunoblot with cow's milk, chicken egg or meat allergic human patients' sera. Biological value indices (True Digestibility (TD), Net Protein Utilisation (NPU), Biological Value (BV)) were determined using rat feeding trials. Among the MDMH products, the pancreatic hydrolysate proved to be the most favourable in terms of biological value and digestibility as well as hypoallergenic property.
\end{abstract}

\section{KEYWORDS}

turkey meat, digestive enzymes, hydrolysis, SDS-PAGE, immunoblot

\footnotetext{
*Corresponding author. Tel.: +36 1796 0412. E-mail: Takacs.Krisztina@uni-mate.hu
} 


\section{INTRODUCTION}

Enzymatic hydrolysates of plant or animal proteins have been used for a long time in many fields, especially in the food industry. For malnourished individuals or in case of certain diseases linked with reduced absorption capacity of the body and injured gastrointestinal function, it is particularly appropriate to use pre-digested proteins, where pre-hydrolysis mimics the gastrointestinal digestion processes.

Food containing peptides does not cause such hypertension as free amino acid mixtures, so as nitrogen source it improves the efficiency of absorption and reduces osmotic problems. According to the latest nutrition and food science aspects, knowledge on biological activity of peptides and proteins in foods is important (Sánchez and Vázquez, 2017).

Determination of the allergenic nature of proteins and peptides has a significant importance, as both food allergies and the inhaled allergies are increasing worldwide and cross-allergenicity can also occur (Hilger et al., 2017). There is a need for products that do not cause allergies, on the one hand to prevent further responses of the reactive immune system of people who are sensitive to specified proteins, and on the other hand to prevent through proper nutrition healthy individuals to develop sensitivity to proteins. Industrial solutions currently used in the production of hypoallergenic products are heat treatment, enzymatic treatment, or the combined use of both.

Heat treatment leads to denaturation of proteins, change in the conformational epitopes. Unfortunately, heat treatment can produce toxic by-products from proteins, and also reduces the bioaccessibility and the bioavailability of the amino acids essential for the human body. The enzymatic treatment causes modification in the sequential and conformational epitopes (Ramirez et al., 1996).

To produce food protein hydrolysates, bacterial, fungal, plant, or animal tissue derived proteases are widely used (Chalamaiah et al., 2018). Exo- and endopeptidases of the gastrointestinal tract are preferred to enzymatic hydrolysis, as they can copy "in vitro" the functioning of the gastric and intestinal enzymes. According to the literature, the in vitro determination of the protein digestibility is mostly carried out by pancreatin treatment (Abd-El-Aal, 1992).

The enzymatic hydrolysates of meat proteins are often used as food additives due to their good flavour impact and favourable functional properties for example in soups and sauces (Sun et al., 2010), and by such enzymatic treatment mechanical deboned meat residues can also be reutilised. The sulphur-containing amino acids, which are in appropriate portion in meat proteins, have special protection properties, and therefore, the product can also increase nutritional safety. From the residue of mechanically boned turkey, mostly hydrolysate containing amino acids and small peptides can be prepared by proteinase treatment (Fonkwe and Sigh, 1996), which may be used in dietary foods and hypoallergenic formulae. Furthermore, it is a natural mineral source being rich in $\mathrm{Ca}, \mathrm{P}, \mathrm{K}$ and $\mathrm{Mg}$.

Several articles on digestion simulation are available, mostly on milk, but literature on meat is scarce. The enzymatically pre-digested muscle proteins can fulfil specific dietary requirements and be used as hypoallergenic foods. Examining the effect of enzymatic treatment on beef proteins, a Brazilian research group (Oliveira et al., 1995) applied for microbial neutrase, papain, or mixture of trypsin and chymotrypsin enzyme preparation to produce base materials for special diets. The limited enzymatic hydrolysis favourably alters the nutritional properties of food proteins and allows the development of products for special nutritional uses or clinical 
purposes (Schaafsma, 2009). The hydrolysis by digestive enzymes reduces allergenic activity (Hall et al., 2018) and improves digestibility and absorption properties (Tavano, 2013).

In the case of milk protein allergy, meat proteins as milk-substitute can be suitable as infant formula foods, particularly turkey meat proteins due to their low allergenicity (Hemmer et al., 2016).

For sportsmen, hydrolysates can be used as fast sources of amino acids without burdening the digestive system and protecting the immune system by healthy diet (Manninen, 2009).

Our aim was to produce by proteolysis meat-based protein hydrolysate products with improved absorptive properties, digestibility, designed functional and good sensory features, and even with hypoantigenic properties, which can substitute milk in formula foods for milk allergic patients. For this purpose, our task was to set up a pre in vitro experiment to monitor the effect of the gastrointestinal digestive enzymes on meat. The hydrolysates then submitted to in vivo feeding experiment demonstrated the suitable digestibility and biological value of the developed product.

\section{MATERIALS AND METHODS}

\subsection{Raw material}

Chilled mechanically deboned turkey meat (pulp) was obtained from a poultry processing factory (Budapest). Pork meat was used as control for the immunoblot analyses. Protein content of meat separates was $20 \%(\mathrm{w} / \mathrm{v})$.

\subsection{Enzymes used}

Digestive enzymes as trypsin (TRY; Sigma, from bovine pancreas, Type IX 13700 BAEE U/mg protein), $\alpha$-chymotrypsin ( $\alpha$-CHY; Sigma, Type II, lyophilised powder from bovine pancreas, $\geq 40 \mathrm{U} \mathrm{BTEE} / \mathrm{mg}$ protein), mixture of trypsin and $\alpha$-chymotrypsin in 1:1 (TRY $+\alpha$-CHY), pancreatin (Sigma, from porcine pancreas, amylase $>100 \mathrm{U} / \mathrm{mg}$ protein) were used for the enzymatic treatment.

\subsection{Human sera}

Clinically proved pooled meat-, chicken egg-, or cow's milk allergic human sera (IgE positive) were used for monitoring the IgE-reactivity of meat proteins.

\subsection{Determination of chemical content}

The crude content composition of the samples was determined according to the relevant international standards. The crude protein content $(\mathrm{N} \times 6.25)$ was measured by Kjeldahl method (AOAC 920.87), the crude fat content by Soxhlet extraction (AOAC 960.39), and the ash content gravimetrically (AOAC 923.03).

\subsection{Enzymatic treatment}

MDMs were adjusted to 2, 6 and $12 \%(\mathrm{w} / \mathrm{v})$ of meat protein in $0.1 \% \mathrm{NaHCO}_{3}$ buffer solution, then homogenised by Ultra Turrax device at 25,000 r.p.m. The $\mathrm{pH}$ of the obtained protein suspension was adjusted to the optimum value corresponding to the enzyme activity ( $\mathrm{pH} 7.5$ ), 
and then the proper enzyme was added. TRY and $\alpha$-CHY were adjusted to 50 TAME units (corresponds to 550 BAEE units) and 250 BTEE units, respectively, in $1 \mathrm{~g}$ meat protein substrate. When the two enzymes were used together, for the first half of the hydrolysis, only TRY was added to the substrate with 25 TAME units/g of adjusted activity. In the second half of the enzyme treatment, $\alpha$-CHY was given to the reaction mixture with 125 BTEE units/g adjustment. As for pancreatin, its TRY component is the most appropriate enzyme in terms of protein hydrolysis, so the amount of pancreatin added was based on trypsin assay and was applied as 50 TAME units/g. Enzyme activities were measured according to Hummel (1959).

The mixture was incubated with continuous stirring in a thermostat at $37{ }^{\circ} \mathrm{C}$ for different times $(60,80,100,120 \mathrm{~min})$. The reaction was terminated by instantaneous boiling ( $5 \mathrm{~min})$, the reaction mixture was cooled immediately, then was frozen and lyophilised. Pork meat as control was only adjusted to $6 \%(\mathrm{w} / \mathrm{v})$ of meat protein solution, and only treated with pancreatin for 60 min. In the preliminary experiments, the hydrolysates $(\mathrm{H})$ were prepared from $15 \mathrm{~g}$ of turkey meat, and in the case of model turkey (T) and pork (P) meat products, from $300 \mathrm{~g}$ (signed as T0: without any enzyme, TI: treated with TRY $+\alpha$-CHY, TII: treated with $\alpha$-CHY, TIII: treated with TRY, TIV: treated with pancreatin), P0: without any enzyme, PI: treated with pancreatin).

\subsection{Determination of the degree of hydrolysis $(\mathrm{DH}, \%)$}

The efficiency of enzymatic breakdown was measured by trinitrobenzenesulfonic acid (TNBS) method according to Adler-Nissen (1979). The free amino groups with TNBS form a yellow reaction product at $340 \mathrm{~nm}$. DH (\%) is obtained by comparing the extinction of the enzymatic hydrolysate with the extinction of the complete hydrolysate prepared by $6 \mathrm{M}$ hydrochloric acid hydrolysis. Results can be calculated by the following formula: number of total amino groups/ free amino groups $\times 100$.

\subsection{SDS-PAGE}

Protein separation was performed by Mini Protean II. device (BIO-RAD) according to Laemmli protocol (1970). Acrylamide concentration of stacking gel and running gel were $6 \%$ and $15 \%$, respectively. The protein bands were stained with Coomassie brilliant blue R250 dye.

\subsection{Immunoblot by human sera}

The separated protein fractions were transferred to a nitrocellulose membrane by the means of Semi-Dry-Blot (Bio-Rad) apparatus. The membrane was incubated first in human sera (IgE), then in goat anti-human IgE secondary antibody conjugated with horseradish peroxidase (HRP). Finally, the antigen-antibody complex was stained with 4-chloro-naphtol in the presence of hydrogen peroxide.

\subsection{Determination of Biological Value Indices in rats by in vivo animal experiment}

Wistar male rats weighing $43 \pm 2$ g were housed in cages separately in three groups (5 rats/ group). Each group was also set in duplicate.

The preliminary adaptation and experiment periods were 3 and 10 days, respectively. The rats were fed with iso-energetic and iso-protein semi-synthetic diet adjusted to $10 \%$ protein content (Table 1). Trypsin/chymotrypsin-treated turkey meat product (TI) or pancreatin-treated turkey meat product (TIV) were the protein source of the diets. 
Table 1. Protein content and composition of animal experimental diet $(\mathrm{g} / 100 \mathrm{~g})$

\begin{tabular}{|c|c|c|c|c|c|c|c|c|c|}
\hline Groups & $\begin{array}{l}\text { Protein } \\
\text { content }\end{array}$ & Meat & $\begin{array}{l}\text { Potato- } \\
\text { starch }\end{array}$ & $\begin{array}{l}\text { Corn- } \\
\text { starch }\end{array}$ & $\begin{array}{c}\text { Sunflower } \\
\text { oil } \\
\text { (g/100 g) }\end{array}$ & Glucose & $\begin{array}{c}\text { Vitamin } \\
\text { supplement }\end{array}$ & $\mathrm{NaCl}$ & $\begin{array}{c}\text { Mineral } \\
\text { supplement } \\
\text { ÁP-17 }\end{array}$ \\
\hline Control & 1.0 & - & 10 & 57 & 15 & 15 & 2 & 0.5 & 0.5 \\
\hline TI & 11.8 & 12 & 10 & 45 & 15 & 15 & 2 & 0.5 & 0.5 \\
\hline TIV & 10.5 & 11 & 10 & 46 & 15 & 15 & 2 & 0.5 & 0.5 \\
\hline
\end{tabular}

The control group was fed only with the experimental diet without any meat-protein source. Faeces of individual rats were collected daily for all 10 days of the experiment period and analysed for total nitrogen. Nitrogen intake, body weight, body nitrogen content, and the faecal nitrogen losses were determined to calculate biological value indices as Net Protein Ratio (NPR), True Digestibility (TD), Net Protein Utilisation (NPU), and Biological Value (BV) according to the following formulae (Miller, 1963; Hegedüs et al., 1981):

Net Protein Ratio, NPR (g/g N): $\left(M_{10}-M_{0}\right)-\left(M_{\mathrm{c} 10}-M_{\mathrm{c} 0}\right) / I$.

True Digestibility, TD (\%): $\left(I-\left(F-F_{\mathrm{c}}\right) \times 100\right) / I=$ TD.

Net Protein Utilisation, NPU (\%): $\left(\left(B-B_{c}\right)+I_{c} \times 100\right) / I$.

Biological Value, BV (\%): $($ NPU $\times 100) /$ TD.

$M\left(\right.$ and $\left.M_{c}\right)=$ average body weight of test (and control) group $(\mathrm{g})$.

$I$ (and $\left.I_{c}\right)=$ average intake nitrogen of test (and control) group (g).

$F\left(\right.$ and $\left.F_{c}\right)=$ faecal nitrogen excretion of test (and control) group $(\mathrm{g})$.

$B$ (and $B_{c}$ ) = average nitrogen content of dried carcasses of test (and control) group (g).

$c=$ control.

$10=10$ th day of feeding trial; $0=0$ th day of feeding trial.

\subsection{Determination of sensory properties}

Freeze-dried turkey meat products were analysed by expert profile analysis (dimensionless scale) and additional consumer preference studies using PSA System3 2.04 software. As the appropriate commercially available freeze-dried protein powders, the hydrolysed product was mixed in $1 \mathrm{~g} / 100 \mathrm{~g}$ ratio with creamy milk product ("kefír", containing $1.4 \%$ milk fat) as a carrier material and given to be judged. At both methods, results were compared to the control "kefír" to carry out quality assessment.

\section{RESULTS AND DISCUSSION}

Our aim was to make a hydrolysed meat product, and for this purpose different experimental steps were needed to be implemented. Our task was to optimise the reaction parameters of the hydrolysis, which meant to determine the appropriate substrate concentration and to select the digestive proteases for the subsequent production. Afterwards, the effect of longer reaction time of the selected enzymes was analysed based on the changes in the protein distribution. In all cases, the efficiency of hydrolysis was assessed by SDS-PAGE and confirmed by TNBS method (DH, \%).

The meat protein substrate concentration was fixed at 2, 6 and $12 \%(\mathrm{w} / \mathrm{v})$. Pancreatic $\mathrm{NaHCO}_{3}$ content ensures an alkaline $\mathrm{pH}(\mathrm{pH} 7.1-8.4)$, so the $\mathrm{pH}$ of the meat suspension has 
been adjusted with $0.1 \% \mathrm{NaHCO}_{3}$ to $\mathrm{pH} 7.5$ in order to model the enzyme running conditions. At this step, trypsin and $\alpha$-chymotrypsin individually and also together were used (for $60 \mathrm{~min}$ ). As the substrate concentration increased, a decrease in $\mathrm{DH} \%$ was found in all three cases. $\mathrm{DH}$ (\%) values at 2, 6 and $12 \%(\mathrm{w} / \mathrm{v})$ are the followings: for trypsin: $38,24.1,16.3$; for $\alpha$-chymotrypsin: $34.8,22.4,18$, and in case of the combined use of the two enzymes: $26.6,20.1,14.5$, respectively. $\mathrm{DH}(\%)$ data gave better information about the hydrolysis than the SDS-PAGE pattern, but the SDS-PAGE images also confirmed (data not shown) that limited hydrolysis was effective, but the product did not contain higher proportion of small peptides than it was desired. In addition, taking into consideration the consistency of the reaction mixture and the efficiency of the enzymatic treatment, it has been found that for a pre-hydrolysed product the most suitable substrate concentration was $6 \%(\mathrm{w} / \mathrm{v})$. Further investigations have been performed with this optimised parameter.

Figure 1 shows the effects of the applied different proteases in the case of the chosen $6 \%(\mathrm{w} /$ v) turkey meat protein/enzyme suspension in terms of DH (\%). It can be concluded that the combined effect of trypsin and chymotrypsin did not increase the degree of hydrolysis better than the trypsin or the $\alpha$-chymotrypsin individually. Hydrolysis (for $60 \mathrm{~min}$ ) by pancreatin offered slightly higher $\mathrm{DH}(\%)$ value: 31 . A primary difference between trypsin and chymotrypsin enzymes is that they break down different amino acids. Chymotrypsin breaks down tryptophan, phenylalanine, and tyrosine. Trypsin breaks down lysine and arginine. So the degree of hydrolysis can cause similarity (as in our case), or differences depending on the substrate specificity. Pancreatin is a powdered pancreatic extract derived from porcine pancreas that contains enzymes secreted by the pancreas, such as lipase, $\alpha$-amylase, trypsin, chymotrypsin, and other proteases. In case of the enzyme mixture of pancreatin, trypsin and chymotrypsin are the main protein degrading enzymes, the activities of the enzyme-mixture can cause similar or higher results compared to trypsin or chymotrypsin hydrolyses.

In case of the $6 \%(\mathrm{w} / \mathrm{v})$ turkey meat protein/enzyme suspension, we tested the effect of the increased reaction time $(60,80,100$, and $120 \mathrm{~min})$ of the gastrointestinal enzymes (separately and combined applications) on hydrolysis. As the reaction time increased, the degree of hydrolysis slightly increased: for trypsin: 24.1, 26.1, 31, 31.1, for $\alpha$-chymotrypsin: $22.4,25.8,30.4$,

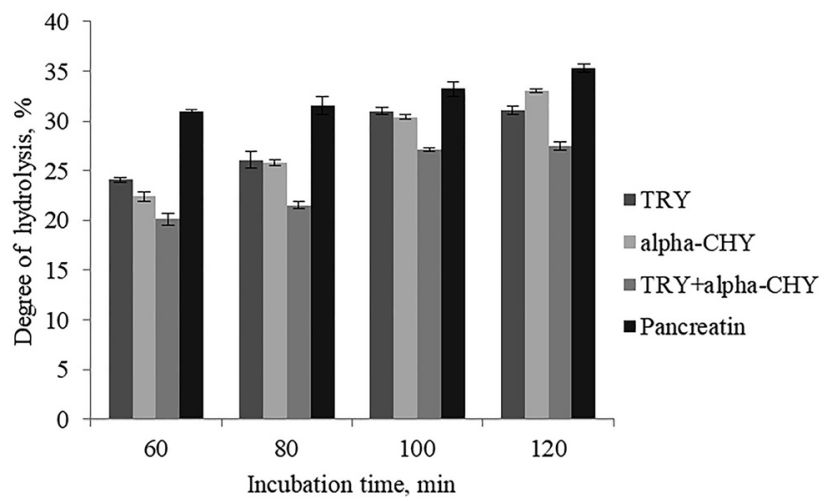

Fig. 1. Effects of the different proteases and incubation times on $\mathrm{DH}(\%)$ of turkey meat hydrolysates (protein content: $6 \%(\mathrm{w} / \mathrm{v})$, at $\mathrm{pH} 7.5,37^{\circ} \mathrm{C}$ ) 
33 , for mixture solution of trypsin and $\alpha$-chymotrypsin: 20.1, 21.5, 27.1, 27.5, and for pancreatin: $31,31.6,33.2,35.3$, respectively. Since only a slight difference was detectable in the results of the four adjusted reaction times, the meat products were prepared with 60 -min enzyme treatment for further examinations. The 60 -min reaction time is sufficient to the desired number of peptide splitting, and the additional incubation time does not cause significant and subservient change. Further conclusion is that pancreatin enzyme gave the highest $\mathrm{DH}$ (\%) out of the all enzymatic treatments.

The following step was to prepare meat products $(300 \mathrm{~g})$ and to analyse the effects of various gastrointestinal enzymes reacting for $60 \mathrm{~min}$. The protein distribution and the $\mathrm{DH}(\%)$ of the hydrolysed meat products can be seen in Fig. 2A. Average reduction in the number of protein bands can be observed for the hydrolysates as compared to the unmodified turkey

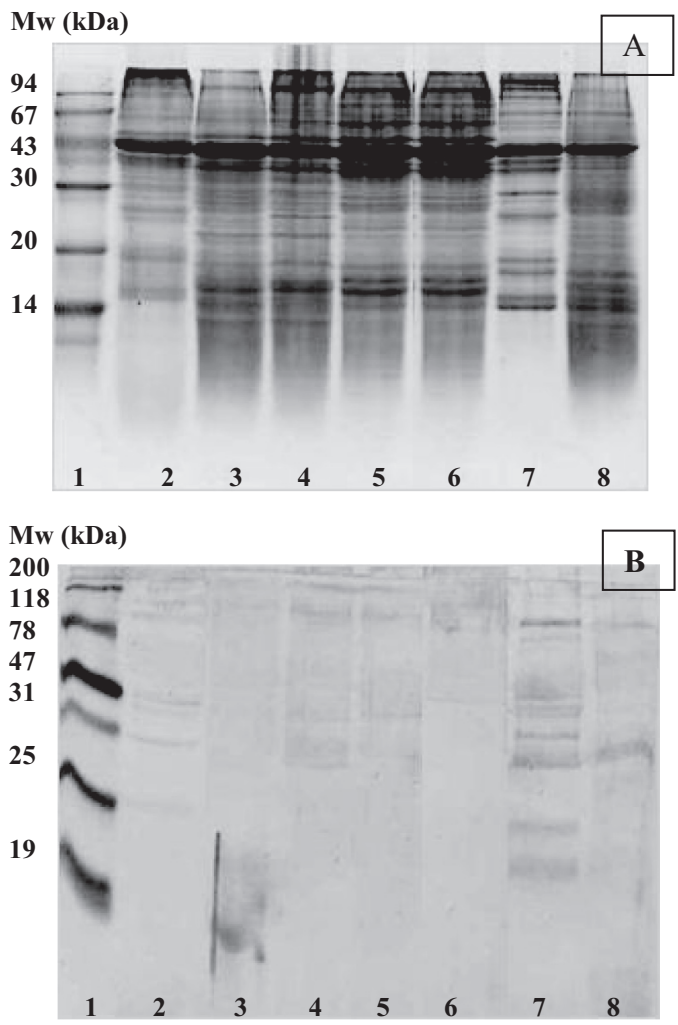

Fig. 2. SDS-PAGE (A) and immunoblot (B) patterns of turkey $(\mathrm{T})$ and pork $(\mathrm{P})$ meat products. 1. Mw, 2. T0 turkey meat product control (without any enzymes) (DH\%: 8.9), 3. TI turkey meat product treated with trypsin and $\alpha$-chymotrypsin (DH\%: 35.6), 4. TII turkey meat product treated with $\alpha$-chymotrypsin (DH\%: 33.1), 5. TIII turkey meat product treated with trypsin (DH\%: 34.3), 6. TIV turkey meat product treated with pancreatin (DH\%: 39.4), 7. P0 pork meat product control (without any enzymes) (DH\%: 7.2), 8. P1 pork meat product treated with pancreatin (DH\%: 26). For immunoblot, meat positive pooled serum was used 
meat, but the major protein bands specific to the turkey meat are still detectable. As it was a partial hydrolysis (for the purpose to improve the digestibility of proteins), an expected decrease in the intensity of proteins and also a partial protein rearrangement was noticed in the range of $10-100 \mathrm{kDa}$.

The allergenic activity of the proteins in meat products was studied with meat, chicken egg, or cow milk IgE-positive human sera by immunoblot. The immunoblotting protein pattern of the unmodified meat and the enzyme-treated products showed that pork meat control sample triggered more intense protein response (IgE-reactive) against the meat positive pooled serum compared to the turkey meat, where few bands were stained only as weak antigens (Fig. 2B).

Cow's milk and chicken egg-positive pooled human sera did not indicate immune response either with the untreated or the enzymatically modified samples (data not shown), so the enzymatically modified products can be recommended for milk - and egg sensitive patients for regular consumption.

The overall acceptance of the hydrolysates in sensory examinations was good, which is illustrated in Fig. 3. The sensory profiles of turkey meat product samples were very similar except for TI (turkey meat product treated with trypsin and $\alpha$-chymotrypsin). It was observed that samples had slightly yellowish colour. Similar results were obtained by other researchers, that hydrolysates of defatted round scad had a brownish yellow colour, presumably caused by pigment oxidation and Maillard reaction during hydrolysis (Hou et al., 2011). The evaluators found TI a bit bitter, while TII, TIII, and TIV had an acceptable neutral taste.

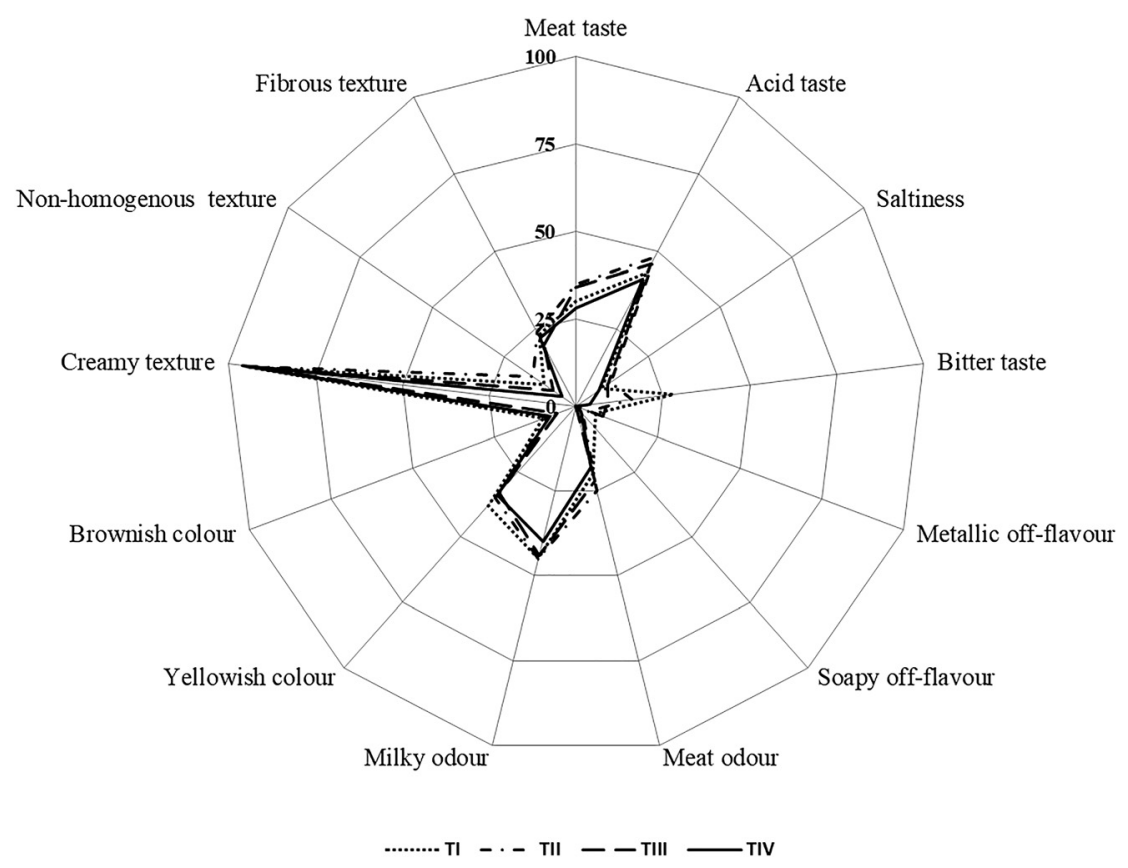

Fig. 3. Sensory profile of the meat-based hydrolysates mixed into kefír 
Partial hydrolysis results in partially hydrolysed polypeptides, which have a bitter aftertaste. Enzymes with different specificities give the hydrolysates different sensory characteristics. Bitter taste of protein hydrolysates is mainly caused by low molecular weight peptides composed of hydrophobic amino acid residues and oligopeptides, and therefore, the specificity of the enzyme used is decisive for the amount of such peptides produced during hydrolysis (Hou et al., 2011). Bitter peptides occur to a varying degree after hydrolysis of most food proteins. Furthermore, bitter taste seems to be related to a high degree of hydrolysis.

The lipid content makes MDM hydrolysate extremely susceptible to oxidation and degradation during processing, excessive lipids may adversely affect quality, due to oxidised lipids interacting with proteins, which could result in off-flavour of the protein product (Jin et al., 2014). For production of meat hydrolysates, according to our results, the enzyme was selected, the degree of hydrolysis and the changes in the protein composition of hydrolysates were examined, and allergenic activity and the sensory properties were considered. In view of the above mentioned results, for the final product both the mixture solution of trypsin and $\alpha$ chymotrypsin and the pancreatic enzyme are recommended to be applied for $60 \mathrm{~min}$ at $37^{\circ} \mathrm{C}$ and $\mathrm{pH} 7.5$.

Because the DH (\%) of TI and TIV was the highest, they were chosen for in vivo animal feeding study to determine the biological value and digestibility of the produced meat-based hydrolysates. Groups consumed diet enriched with trypsin/chymotrypsin-treated turkey meat product (TI product with a protein content of 83.6\%), and with pancreatin-treated turkey meat product (TIV product with a protein content of $90.55 \%$ ). The endogenous protein losses were determined by using a control group.

The average (relative) body weight changes during the 10 days were $32 \mathrm{~g}$ for TI product and $26.5 \mathrm{~g}$ for TIV product consumption. The body weight of the control group remained at approximately the same level. The average (relative) feed intakes (I) of the TI and TIV product groups were $68.8 \mathrm{~g} \mathrm{~N} / \mathrm{animal}$ and $61 \mathrm{~g} \mathrm{~N} /$ animal during the 10 days, respectively. During the 10 day feeding trial, essential differences in the net protein ratio (NPR, g/g N) of the two test groups were not detected $(\mathrm{NPR}, \mathrm{g} / \mathrm{g} \mathrm{N}$ : $\mathrm{TI}=4.31 \pm 0.24$; $\mathrm{TIV}=4.66 \pm 0.22)$. The biological value indices are presented in Table 2. The value of net protein utilisation (NPU, \%) was higher in case of the TIV-enriched compared to the TI-enriched diet group.

In terms of digestibility (TD, \%), both diets gave good values, above $90 \%$.

In biological values (BV, \%) relevant differences in net protein utilisation were found, as the TIV-enriched diet consuming group showed better results as the TI-enriched diet consuming group. The difference between the effects of feeding the two types of hydrolysates (TI, TIV) is probably explained by the fact that the pancreatic enzyme has more optimal enzyme activity in terms of protein degradation.

Table 2. Biological value indices (TD, NPU, BV) of turkey meat hydrolysates based protein

\begin{tabular}{|c|c|c|c|c|c|c|c|c|c|c|c|c|}
\hline \multirow{2}{*}{$\begin{array}{l}\text { Groups ( } n= \\
10 \text { rats) }\end{array}$} & \multicolumn{2}{|c|}{$\begin{array}{c}\text { Intake } \\
\text { nitrogen (g) }\end{array}$} & \multicolumn{2}{|c|}{$\begin{array}{c}\text { Faecal } \\
\text { nitrogen }(\mathrm{g})\end{array}$} & \multicolumn{2}{|c|}{$\begin{array}{c}\text { Body } \\
\text { nitrogen (g) }\end{array}$} & \multicolumn{2}{|c|}{$\mathrm{TD}(\%)$} & \multicolumn{2}{|c|}{ NPU (\%) } & \multicolumn{2}{|c|}{ BV (\%) } \\
\hline & Mean & $\mathrm{SD}$ & Mean & $\mathrm{SD}$ & Mean & $\mathrm{SD}$ & Mean & $\mathrm{SD}$ & Mean & $\mathrm{SD}$ & Mean & SD \\
\hline TI & 1.30 & 0.00 & 0.14 & 0.01 & 1.95 & 0.04 & 92.73 & 0.50 & 68.30 & 1.84 & 73.65 & 1.59 \\
\hline TIV & 1.03 & 0.02 & 0.12 & 0.00 & 1.88 & 0.03 & 94.06 & 1.81 & 78.81 & 2.83 & 83.87 & 4.62 \\
\hline
\end{tabular}




\section{CONCLUSIONS}

According to our results it can be stated that the optimum turkey meat substrate concentration for the final product was $6 \%(\mathrm{w} / \mathrm{v})$ for best reaction mixture consistency and efficiency of the enzymatic treatment. The 60 -min reaction time was sufficient for the desired number of peptide splitting, and longer incubation did not cause considerable desirable changes.

Among the applied enzyme modifications, pancreatin enzyme (at $37{ }^{\circ} \mathrm{C}, \mathrm{pH} 7.5$ ) provided sufficient degree of hydrolysation (39.4\%). According to the results of animal feeding experiments, turkey meat pancreatic hydrolysates had the highest biological value $\left(\mathrm{BV}_{\mathrm{Mean}} \%: 84\right)$ and digestibility ( $\mathrm{TD}_{\text {Mean }} \%$ : 94$)$.

The product did not react with cow's milk, chicken egg, or meat allergenic human sera (IgE).

Based on these results, food grade pancreatin is recommended for the production of hypoallergenic infant formula for milk-allergic children for milk-derived food substitution. Furthermore, turkey meat itself can be highly recommended as it is known to be less allergenic than pork meat (Commins et al., 2016).

The hydrolysed product was accepted by test-consumers in the sensory survey, no complaint was raised regarding taste, smell, or consistency. The final product was characterised by $39.2 \mathrm{~g} /$ $100 \mathrm{~g}$ protein content, $48.7 \mathrm{~g} / 100 \mathrm{~g}$ fat content, and $5.28 \mathrm{~g} / 100 \mathrm{~g}$ ash content.

\section{ACKNOWLEDGEMENT}

This research was supported by the "Thematic Excellence Programme" TUDFO/51757-1/2019ITM.

\section{REFERENCES}

Abd-El-Aal, M.H. (1992). Production of guava seed protein isolates: yield, composition and protein quality. Nahrung, 36: 50-55.

Adler-Nissen, J. (1979). Determination of the degree of hydrolysis of food protein hydrolysates by trinitrobenzenesulphonic acid. Journal of Agricultural and Food Chemistry, 17: 1256-1261.

AOAC. (1995). Official methods of analysis of AOAC International, $16^{\text {th }}$ ed. Method no. 920.87, 960.39, and 923.03. Association of Official Analytical Chemists, Arlington, VA, USA.

Chalamaiah, M., Yu, W., and $\mathrm{Wu}$, J. (2018). Immunomodulatory and anticancer protein hydrolysates (peptides) from food proteins: a review. Food Chemistry, 245: 205-222.

Commins, S.P., Jerath, M.R., Cox, K., Erickson, L.D., and Platts-Mills, T. (2016). Delayed anaphylaxis to alpha-gal, an oligosaccharide in mammalian meat. Allergology International, 17: 1256-1261.

Fonkwe, L.G. and Sigh, R.K. (1996). Protein recovery from mechanically deboned turkey residue by enzymic hydrolysis. Process Biochemistry, 31: 605-616.

Hall, F., Johnson, P.E., and Liceaga, A. (2018). Effect of enzymatic hydrolysis on bioactive properties and allergenicity of cricket (Gryllodes sigillatus) protein. Food Chemistry, 262: 39-47. 
Hegedűs, M., Kralovánszky, U.P., and Mátrai, T. (1981). A takarmányfehérjék minősitése. (A takarmányozás elmélete és gyakorlata) (The qualification of feed proteins. (Theory and practice of feeding)). Mezőgazdasági Kiadó, Budapest, pp. 1-346.

Hemmer, W., Klug, C., and Swoboda, I. (2016). Update on the bird-egg syndrome and genuine poultry meat allergy. Allergo Journal International, 25: 68-75.

Hilger, C., van Hage, M., and Kuehn, A. (2017). Diagnosis of allergy to mammals and fish: cross-reactive vs. specific markers. Current Allergy and Asthma Reports, 17(9): 64.

Hou, H., Li, B. and Zhao, X. (2011). Enzymatic hydrolysis of defatted mackerel protein with low bitter taste. Journal of Ocean University of China, 10(1): 85-92.

Hummel, B.C. (1959). A modified spectrophotometric determination of chymotrypsin, trypsin, and thrombin. Canadian Journal of Biochemistry and Physiology, 37: 1393-1399.

Jin, S.K., Go, G.W., Jung, E.Y., Lim, H.J., Yang, H.S., and Park, J.H. (2014). Effect of mechanically deboned chicken meat hydrolysates on the physicochemical properties of imitation fish paste. Asian-Australasian Journal of Animal Sciences, 27(1): 115-122.

Laemmli, U. K. (1970). Cleavage of structural proteins during the assembly of the head of bacteriophage T4. Nature, 227 (5259), 680-685.

Manninen, A.H. (2009). Protein hydrolysates in sports nutrition. Nutrition \& Metabolism, 6: 38-42.

Miller, D.S., (1963). A procedure for determination of NPU using rats body-N technique evaluation of protein quality. In: Evaluation of protein quality. National Academy of Sciences - National Research Council Publications, 1100: pp. 34-40, Washington, D.C.

Oliveira, M.N., Baruffaldi, R., and Pitombo, R.N. (1995). Process of enzymic modification of the proteic matrix of bovine meat. Alimentos e Nutricao, 6: 15-23.

Ramirez, J.A., Bandman, E., Wick, M., and Martin Polo, P.O. (1996). Protein structure similarities between fish and chicken skeletal muscle myosin employing monoclonal antibodies. IFT annual meeting. Book of Abstracts p. 81.

Sánchez, A. and Vázquez, A. (2017). Bioactive peptides: a review. Food Quality and Safety, 1: 29-46.

Schaafsma, G. (2009). Safety of protein hydrolysates, fractions thereof and bioactive peptides in human nutrition. European Journal of Clinical Nutrition, 63: 1161-1168.

Sun, W., Zhao, M., Cui, C., Zhao, Q., and Yang, B. (2010). Effect of Maillard reaction products derived from the hydrolysate of mechanically deboned chicken residue on the antioxidant, textural and sensory properties of Cantonese sausages. Meat Science, 86: 276-282.

Tavano, O.L. (2013). Protein hydrolysis using proteases: an important tool for food biotechnology. Journal of Molecular Catalysis B, 90: 1-11.

Open Access. This is an open-access article distributed under the terms of the Creative Commons Attribution 4.0 International License (https://creativecommons.org/licenses/by/4.0/), which permits unrestricted use, distribution, and reproduction in any medium, provided the original author and source are credited, a link to the CC License is provided, and changes - if any - are indicated. (SID_1) 